\title{
Support Vector Regression (SVR) Dalam Memprediksi Harga Minyak Kelapa Sawit di Indonesia dan Nilai Tukar Mata Uang EUR/USD
}

\author{
(Support Vector Machine (SVM) To Predict Crude Oil Palm in Indonesia \\ and Exchange Rate of EUR/USD)
}

\author{
Siti Saadah*, Fakhira Zahra Z, Hasna Haifa Z \\ Program Studi S1 Informatika, Fakultas Informatika - Telkom University \\ Jl. Telekomunikasi No.1, Bandung West Java 40257 Indonesia \\ Email: sitisaadah@telkomuniversity.ac.id, [firafakhira,hasnahaifaz]@student.telkomuniversity.ac.id
}

\section{"Penulis Korespondensi}

\begin{abstract}
Support Vector Regression (SVR) is algorithm machine learning that had been used so often to model and predict non-linear cases. Using kernel radial basis, it succeeds in tackling seasoning problem, like in this pandemic situation. According to its capability, then in this study will predict forex exchange rate and price of crude palm oil (COP). Measuring the system performance with the best hyperparameter hyperparameters $\mathrm{C}=1 \mathrm{e} 3$, Gamma $=0.1$, dan Degree $=3$, the result indicates $99.97 \%$ accuracy in predicting exchange rate EUR/USD based on MAPE calculation. Whereas it reaches $98 \%$ accuracy in doing prediction of COP refer to MSE equation. Those values are the best performance among all prediction attempts.
\end{abstract}

Key words: Prediction, Forex, EUR/USD, MSE, MAPE, Support Vector Regression (SVR).

\section{PENDAhUluaN}

Indonesia sebagai negara berkembang memiliki banyak parameter yang berkaitan mengenai stabilitas perekonomian maupun keuangan, baik secara langsung atau tidak. Berangkat dari hal tersebut, maka diperlukan sebuah penelitian lebih lanjut menggunakan pendekatan pembelajaran mesin, dalam hal ini algoritma Support Vector Regression - SVR menggunakan kernel radial basis (RBF), untuk memprediksi perwakilan indikator makroekonomi [34]. Pada pembelajaran ini, akan di kaji dua permasalahan yang sering ditemui Bank Indonesia maupun Kementerian Perekonomian terkait dengan stabilitas kondisi keuangan bangsa yaitu prediksi mengenai pertukaran nilai mata uang Indonesia terhadap EUR/USD dan pengamatan mengenai prediksi harga minyak kelapa sawit [35] [36].

Beberapa penelitian telah dilakukan terkait prediksi nilai tukar rupiah terhadap dolar Amerika Serikat, seperti pada tahun 2017, Sucipto dan Zyen [6] menggunakan 1689 dataset memperoleh akurasi prediksi $97,86 \%$ dengan model SVM metode kernel trick. Kemudian pada tahun 2018 peneliti Enri, dkk [5] melakukan penelitian dengan hasil prediksi exchange rate menggunakan SVR dengan kernel radial basis yang dioptimasi dengan PSO memperoleh akurasi 78,2\%. Dan pada tahun 2020, Mufni dan Metty [32] melakukan pembelajaran mengenai prediksi untuk nilai tukar rupiah dengan dolar menggunakan SVR di mana akurasi yang diperoleh berada pada kisaran 95\%. Mengacu kepada penelitian sebelumnya, maka pada penelitian ini dikaji mengenai prediksi forex nilai tukar mata uang EUR/USD menggunakan algoritma SVM model Support Vector Regression (SVR) dengan kernel Radial Basis Function (RBF) menggunakan data pada saat pandemi covid-19. Dan penelitian ini adalah pembelajaran lanjutan terhadap penelitian yang dipublikasikan pada akhir tahun 2020 [11] yakni mengenai prediksi Forex Trading menggunakan algoritma deep learning yaitu LSTM.

Sedangkan, mengacu kepada indikator lain yaitu hasil bumi Bangsa Indonesia, maka harga minyak kelapa sawit menjadi permasalahan yang akan dibahas pada penelitian ini. Indonesia sebagai negara nomor 1 (satu) penghasil minyak kelapa sawit di dunia, sudah seyogianya memiliki pendekatan menggunakan algoritma pembelajaran mesin untuk memprediksi pergerakan harga minyak kelapa sawit (atau dalam Bahasa inggris di sebut dengan COP-Crude Oil Price). Dikarenakan penyelesaian terhadap harga jual kelapa sawit yang mengalami ketidakpastian membuat beberapa investor dan/atau pembeli kesulitan untuk memperkirakan harga jual pada periode mendatang. Dan hal ini akan mempengaruhi pengambilan keputusan mengenai kebijakan terkait perekonomian dan keuangan di Indonesia.

Dengan Support Vertor Regression (SVR) sebagai alat bantu yang dapat memprediksi harga jual kelapa sawit akan dibangun hyperplanes dalam dimensi ruang yang terbatas, yang dapat digunakan untuk klasifikasi atau regresi. Beberapa penelitian terkait hal ini yaitu [12] Yasin dkk, tahun 2016 menggunakan SVR dengan algoritma grid search-cross validation untuk memprediksi harga minyak kelapa sawit. Pada tahun 2019, Hijratul dkk [18] menyimpulkan bahwa algoritma BPNN memperoleh nilai MSE 0.0069 saat memprediksi CPO dari 2015 hingga 
2018 menggunakan data perusahaan minyak kelapa sawit mentah di Paser-Kalimantan Timur. Kemudian pada tahun yang sama Agasta E dkk [28] melakukan prediksi COP di perusahaan daerah Bengkulu menggunakan ELM dan diperoleh hasil MAPE sebesar 21,25\%. Selanjutnya pada tahun 2018, Bonita O dkk [30] melakukan pembelajaran terkait prediksi batu bara menggunakan SVR yang memberikan 9.64\% nilai MAPE menggunakan kernel RBF. Dan pada tahun 2017, Kasturi dkk [21] menyatakan bahwa terdapat keterhubungan antara prediksi COP dan exchange rate dengan menggunakan algoritma pembelajaran mesin SVM, MLP dan Holt Winter Eksponensial.

Oleh sebab itu, mengacu kepada karakteristik data forex exchange dan harga minyak kelapa sawit yang bersifat seasoning dan memiliki tingkat volatile yang tinggi, maka pada studi ini akan diamati mengenai pergerakan data keduanya menggunakan algoritma SVR. Penerapan kernel-SVR oleh Schölkopf diperoleh analisis secara empiris yang menyatakan bahwa SVR dengan kernel radial basis selain lebih mudah digunakan, juga mampu diimplementasikan dalam kasus non-linear. Berdasarkan kemampuan ini, maka kernel RBF pada SVR mampu menghasilkan model dari data pelatihan menjadi berhingga pada dimensi ruang. Dengan demikian, SVR mumpuni untuk memberikan solusi mengenai permasalahan hubungan non linear. Selain itu, mengacu kepada beberapa keunggulan SVR yang dapat dilihat pada Tabel I merupakan hipotesis yang menyebabkan penyelesaian permasalahan prediksi forex exchange dan harga minyak kelapa sawit menggunakan SVR.

TABEL I. KeUNGGULAN SVR

\begin{tabular}{|c|l|}
\hline No & Keunggulan \\
\hline 1 & $\begin{array}{l}\text { SVR mampu memberikan model pelatihan lebih cepat. } \\
\text { Dengan karakteristik untuk memecahkan persamaan linear, } \\
\text { maka algoritma ini lebih cocok untuk data set dengan dimensi } \\
\text { lebih tinggi; }\end{array}$ \\
\hline 2 & $\begin{array}{l}\text { SVR mampu menyelesaikan permasalahan minimal lokal dari } \\
\text { optimasi nonlinier; dan }\end{array}$ \\
\hline 3 & $\begin{array}{l}\text { SVR mampu melakukan penyelesaian norm error pada saat } \\
\text { pinalti outlier selama fase pelatihan. Hal ini yang diketahui } \\
\text { dengan kernel trick; }\end{array}$ \\
\hline 4 & SVR efektif untuk menggeneralisasi sampel data yang sedikit; \\
\hline 5 & SVR mampu menghindari overfiting. \\
\hline
\end{tabular}

Susunan artikel ini terdiri dari bagian I menceritakan mengenai aspek penting dilakukan penelitian terkait prediksi untuk data exchange rate USD/EUR dan harga minyak kelapa sawit. Bagian II menggambarkan pembelajaran literatur terkait studi kasus yang diamati. Sedangkan bagian III merepresentasikan metodologi penelitian. Bagian IV merupakan pemaparan mengenai hasil dan analisis penelitian. Terakhir pada bagian $\mathrm{V}$ akan dipaparkan mengenai kesimpulan dan saran dari hasil penelitian ini.

\section{TINJAUAN PUSTAKA}

\section{A. Support Vector Regression (SVR)}

Algoritma Support Vector Machine (SVM) adalah salah satu metode klasifikasi atau prediksi yang menggunakan hyperplane untuk memisahkan atau mengelompokkan suatu data. SVM memiliki kelebihan yaitu dapat mengatasi overfitting serta memiliki kemampuan yang sangat baik dalam menggeneralisasi sample kecil. Support Vector Regression (SVR) merupakan model regresi dari SVM.

Metode SVR digunakan untuk memecahkan permasalahan non-linear. SVR sukses diterapkan di beberapa permasalahan dalam prediksi time series. Oleh sebab itu, SVR termasuk ke dalam algoritma yang digunakan untuk klasifikasi, identifikasi, regresi, dan analisis time-series. Dengan kemampuan SVR menangani model regresi dengan data yang tidak linear, Persamaan (1) merupakan rumus matematika yang digunakan.

$$
\Upsilon_{t}=\omega_{t} \Phi\left(x_{t}\right)+b
$$

$\Upsilon_{t} \in \Re$ adalah nilai prediksi time series, $\quad x_{t} \in \Re^{D}$ adalah vektor masukan yang terdiri dari data historis, $x_{t}=$ $\left\{y_{t-D}, y_{t-D+1}, \ldots, y_{t-1}\right\}^{T}$, dan $b \in \Re$ adalah bias, $\omega \in$ $\Re^{M}$ adalah vektor bobot dari $x_{t}$ dan $\Phi\left(x_{t}\right) \Re^{D} \rightarrow$ $\mathfrak{R}^{M}(M>D)$ fitur ruang yang mengubah vektor masukan $x_{t} \in \Re^{D}$ melewati ruang dengan dimensi yang lebih tinggi $\Phi\left(x_{t}\right) \in \Re^{M}$. Regressor dari SVR dirumuskan sesuai dengan Persamaan (2) [4]:

$$
\Upsilon_{t}=\sum_{(i=1, N)} \alpha_{i} K\left(x_{t}-x_{i}\right)+b
$$

$\alpha_{i}(i=1, \ldots, N)$ adalah Lagrange multipliers yang tidak negatif dan $K\left(x_{t}, x_{i}\right)$ adalah fungsi kernel, salah satunya kernel RBF (Kernel Radial Basis Funcion) dengan persamaannya sesuai dengan Persamaan (3):

$$
K\left(x_{t}, x_{i}\right)=\exp \left(-\gamma\left\|x_{t}-x_{i}\right\|^{2}\right)
$$

Dengan perumusan loss function (Gunn, 1998) ditunjukkan hubungan antara error dengan error yang dikenai penalti. Pendekatan hasil SVR yang berbeda dapat diperoleh pada saat mengunakan loss function dengan besaran yang tidak sama (Santoso, 2007).

Loss function yang paling sederhana yakni $\varepsilon$ insensitive loss function (Amanda, 2014) dengan formulasi $\varepsilon$-insensitive loss function dapat dilihat pada Persamaan (4) sebagai berikut.

$$
L(\boldsymbol{y}, f(\boldsymbol{x}))=\left\{\begin{array}{c}
0, \text { untuk }|f(\boldsymbol{x})-\boldsymbol{y}|<\varepsilon \\
|f(\boldsymbol{x})-\boldsymbol{y}|-\varepsilon, \text { untuk yang lain }
\end{array}\right.
$$

\section{B. Forex Exchange (Forex)}

Pasar Forex adalah pasar di bidang keuangan dengan karakteristik high benefit, dipengaruhi oleh kondisi suatu 
negara, dan transaksinya dapat dilakukan sepanjang waktu di setiap lokasi di dunia. Para investor dapat membeli atau menjual pasangan mata uang seperti EUR/USD (Euro vs AS Dolar), USDJPY (Dolar AS vs Yen Jepang), GBPUSD (Pound Inggris vs Dolar AS) untuk mendapatkan keuntungan dari nilai tukar yang berbeda antara pasangan.

Gambar 1 merupakan grafik dataset forex yang digunakan dari tanggal 2 September 2019 - 28 Februari 2020, yakni pada sekitar peralihan 2019 ke 2020. Dapat dilihat bahwa pada awal covid-19 merebak, nilai forex mengalami penurunan tajam, atau dengan kata lain dataset forex bersifat seasoning dan volatile.

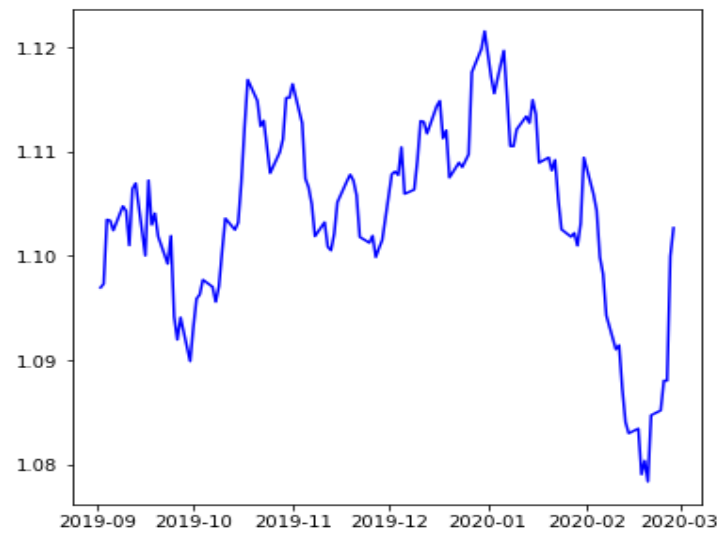

Gambar 1. Grafik Dataset Forex EUR/USD

\section{Minyak Kelapa Sawit (CPO-Crude Palm Oil)}

Indonesia merupakan negara penghasil kelapa sawit pertama di dunia. Terkait hal ini, perkebunan kelapa sawit dapat memberikan keuntungan yang besar untuk negara Indonesia. Dikarenakan kelapa sawit merupakan tumbuhan yang banyak memiliki manfaat seperti untuk memasak, bahan bakar industri. Dengan penyebaran pertumbuhan kelapa sawit di berbagai pulau di Indonesia, diperlukan pemantauan terhadap pergerakan harga jual tidak hanya kepada para investor di dunia pasar, tetapi untuk para petani sawit itu sendiri. Gambar 2 merupakan data harga jual minyak kelapa sawit dari tahun yang diperoleh dari WTI oil price forecast $\mid$ Kaggle

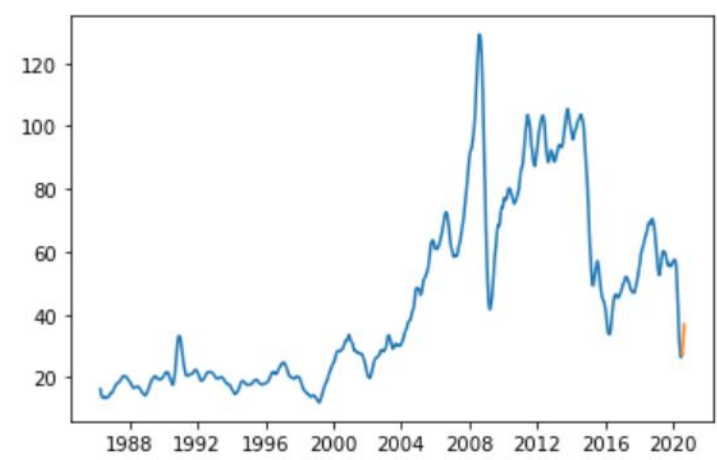

Gambar 2. Grafik Dataset CPO Price

\section{Mean Square Error (MSE)}

Pengukuran kinerja sistem menggunakan MSE memiliki tujuan untuk menghitung hasil prediksi terhadap dataset asli. Hasil dari data uji tersebut akan diukur menggunakan Mean Squared Error (MSE) dengan rumus Persamaan (5) sebagai berikut, dengan $Y_{i}$ adalah nilai perkiraan dan $\hat{Y}_{i}$ adalah nilai sebenarnya

$$
M S E=\frac{1}{n} \sum_{i=1}^{n}\left(Y_{i}-\widehat{Y_{l}}\right)^{2}
$$

\section{E. Mean Absolute Percentage Error (MAPE)}

Mengukur perfomansi menggunakan MAPE dikarenakan MAPE mampu mengukur kesalahan yang relative berdasarkan nilai absolut. Dengan dua keuntungan yang dimiliki oleh MAPE yakni 1) mampu menjaga kebenaran dari nilai negative dan 2) mampu menjaga kesalahan yang relative tidak bergantung pada skala variable dependen. Sehingga memungkinkan untuk membandingkan nilai prediksi time series. Perumusan MAPE dapat dilihat pada Persamaan (6), dengan $y_{i}$ adalah nilai perkiraan dan $y_{i}$ adalah nilai sebenarnya.

$$
\text { MAPE }=\frac{\sum_{i=1}^{n}\left|\frac{y_{i}-y_{i}^{\prime}}{y_{i}}\right|}{n} \times 100
$$

\section{METODE PENELITIAN}

Indonesia merupakan negara berkembang dengan pertumbuhan ekonomi bergantung kepada berbagai macam aspek, mulai dari pertukaran nilai mata uang rupiah dengan mata uang asing, sampai dengan proses ekspor komoditi hasil pertanian. Oleh sebab itu, pertukaran nilai mata uang Indonesia dipengaruhi oleh berbagai mata uang asing, salah satu di antaranya yaitu mata uang EUR/USD. Sedangkan, sebagai negara agraris, Indonesia yang berperan sebagai negara dengan peringkat pertama terbesar di dunia terkait penghasilan minyak kelapa sawit dan tentunya sebagai pengekspor sawit yang diandalkan, mengalami banyak keterkaitan langsung maupun tidak langsung dari pihak internal dan eksternal mengenai harga COP.

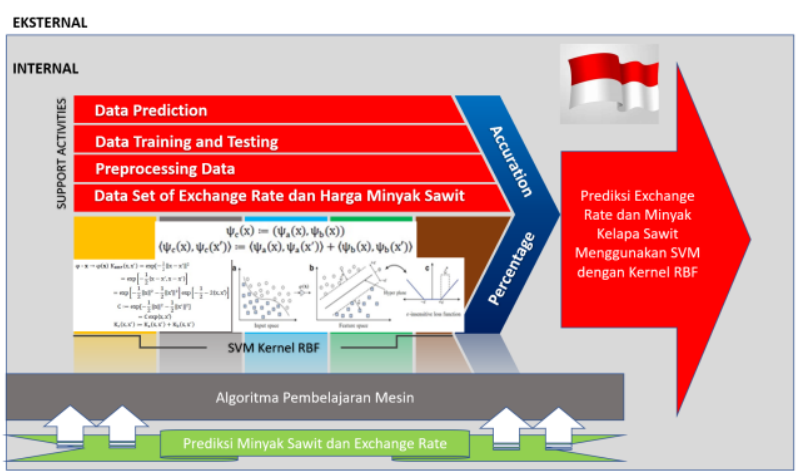

Gambar 3 Sistem Prediksi Minyak Kelapa Sawit dan Foreign Exchange

Mengacu kepada pentingnya dua indikator tersebut di atas, maka pada penelitian ini akan diamati mengenai 
keberhasilan algoritma SVR dalam memprediksi harga minyak kelapa sawit di Indonesia dan pertukaran mata uang Indonesia terhadap EUR/USD. Gambar 3 menunjukkan rangkaian proses sistem pada pembelajaran ini.

\section{A. 3.2 SVR untuk Prediksi Forex}

Untuk penelitian exchange forex ini terbagi kedalam 3fase yakni fase training, testing dan prediksi. Pada fase training dilakukan pemodelan tren mengacu kepada dataset yang digunakan. Kemudian hasil tersebut, akan di ukur pada saat fase testing. Untuk kemudian dari hasil akurasi di proses testing, akan dilakukan prediksi terkait forex market EUR/USD. Gambar 4 berikut merupakan diagram alir sistem terkait urutan langkah metode penelitian yang dilakukan untuk kasus exchange forex.

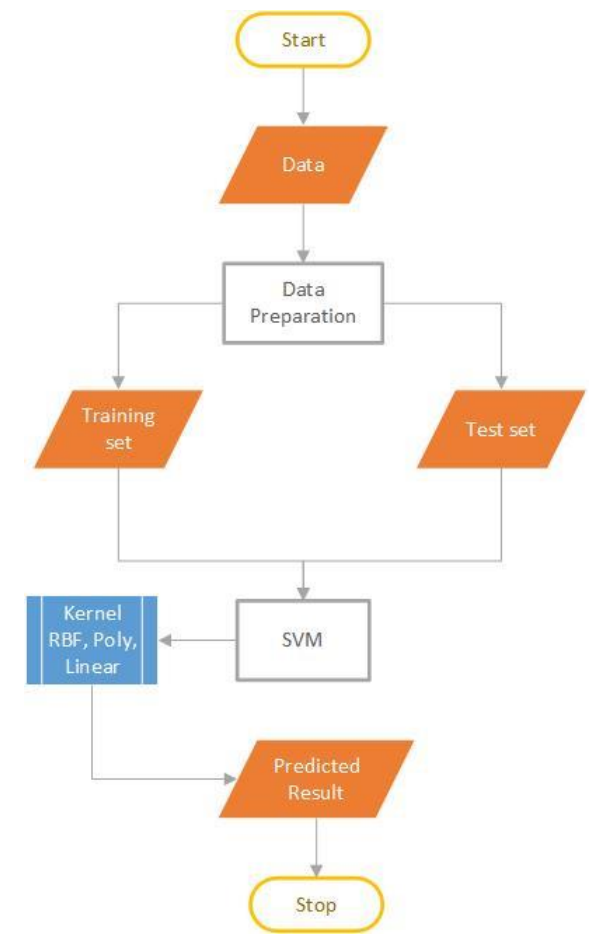

Gambar 4. Diagram Alir SVR untuk Prediksi Forex

Data yang digunakan merupakan pasangan mata uang EUR/USD dari tanggal 2 September 2019 hingga 28 Februari 2020 sebanyak 128 data yang didapatkan dari Tickmill MetaTrader4 dengan timeframe harian. Contoh data set ini dapat dilihat pada Gambar 5.

Support Vector Machine pada pemodelan ini menggunakan metode Support Vector Regression (SVR) dengan tiga kernel yaitu: Linear kernel, Polynomial kernel, dan Radial Basis Function (RBF) atau Gaussian kernel. Parameter yang digunakan untuk 3-kernel SVM yaitu $\mathrm{C}=$ 1e3; Gamma $=0.1$ dan Degree $=3$. Dengan kernel Polynomial dan RBF digunakan untuk mencari hyperplane yang tidak linear. Data latih akan digunakan untuk melatih model SVR.

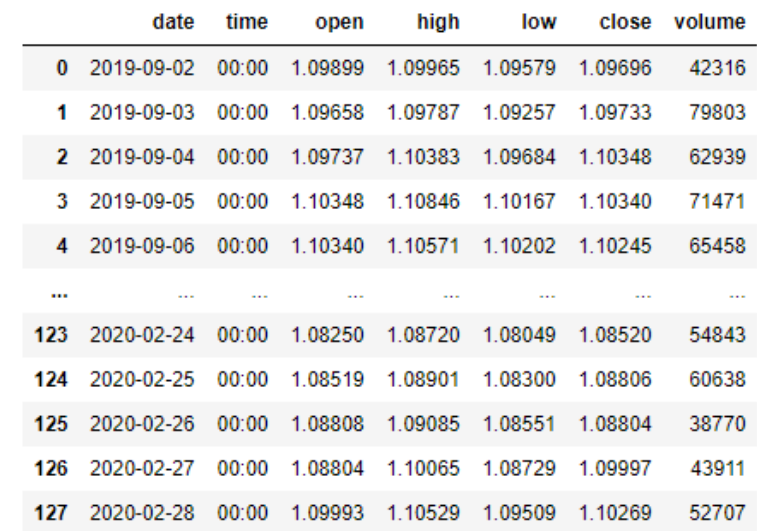

Gambar 5. Dataset EUR/USD

Prediksi yang dilakukan hanya akan menggunakan nilai pada kolom close, Sehingga kolom-kolom data yang tidak digunakan seperti: time, open, high, low, dan volume akan dihilangkan. Berikut merupakan step-by-step preprocessing data yang dilakukan: pertama, mengubah Data date. Data date yang didapatkan berbentuk tanggal untuk itu perlu diubah menjadi integer agar dapat dijadikan dependant variable untuk prediksi ini. Kedua, melakukan normalisasi Data dan Splitting Data. Selanjutnya, dilakukan normalisasi data untuk meminimalisir outliers dan noise pada data date dan close menggunakan MinMax Scaller yang memiliki rumus seperti Persamaan (7).

$$
\tilde{x}=\frac{x-\min (x)}{\max (x)-\min (x)}
$$

data lalu dibagi menjadi data latih dan data uji dengan perbandingan 70:30, selanjutnya model akan melakukan prediksi pada data uji untuk menetukan nilai harga close pada tanggal 16 Januari 2020 hingga 28 Februari 2020.

\section{B. SVR untuk Prediksi Minyak Kelapa Sawit}

Pada proses ini dilakukan pemisahan antara hari dan harga minyak kelapa sawit yang berada dalam satu baris. Lalu data berupa hari dimasukkan ke dalam list hari, sedangkan data harga dimasukkan ke dalam list harga yang akan menjadi target. Pada setiap data harga di kali 100 agar tidak ada angka desimal. Setelah itu, dilakukan proses pemisahan data train dan data test. Langkah melakukan prediksi dapat dilihat pada Gambar 6.

TABEL II. DATA SET COP PRICE

\begin{tabular}{|c|c|}
\hline Date & Value \\
\hline $12 / 28 / 2015$ & 36.81 \\
\hline $12 / 29 / 2015$ & 37.87 \\
\hline $1 / 4 / 2016$ & 36.76 \\
\hline $1 / 5 / 2016$ & 35.97 \\
\hline
\end{tabular}




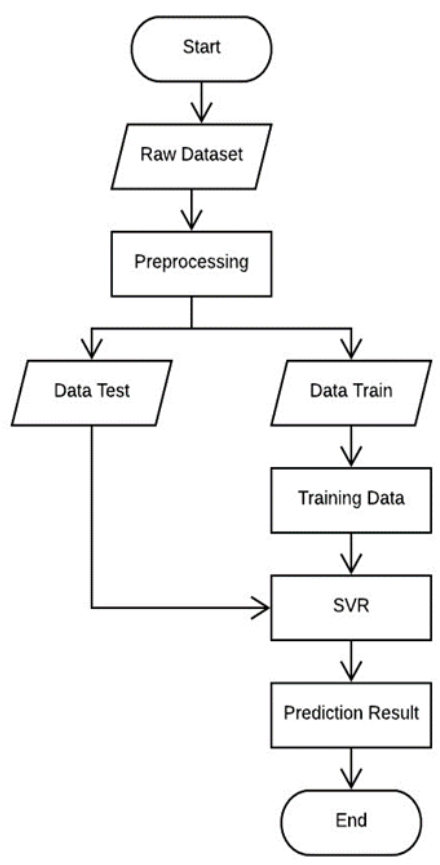

Gambar 6. Diagram Alir SVR untuk Prediksi Minyak Sawit

Data yang digunakan pada sistem ini menggunakan data dari tahun 2015-2018 yang diambil dari WTI crude palm oil dataset (WTI oil price forecast $\mid$ Kaggle). Tabel II menggambarkan contoh tampilan data COP yang digunakan. Adapun code untuk pemrograman ini dapat dilihat melalui link berikut:

https://github.com/firafakhira/SVR-for-Oil-Prediction

\section{HASIL DAN PEMBAHASAN}

\section{A. Hasil dan Analisis Prediksi Forex Menggunakan SVR}

Pengujian dilakukan dengan menggunakan hyper parameter $\mathrm{C}=1 \mathrm{e} 3, \mathrm{Gamma}=0.1$, dan Degree $=3$ untuk memprediksi forex menggunakan kernel RBF dengan kompleksitas algoritma pemodelan ini adalah $O\left(n^{2}\right)$.

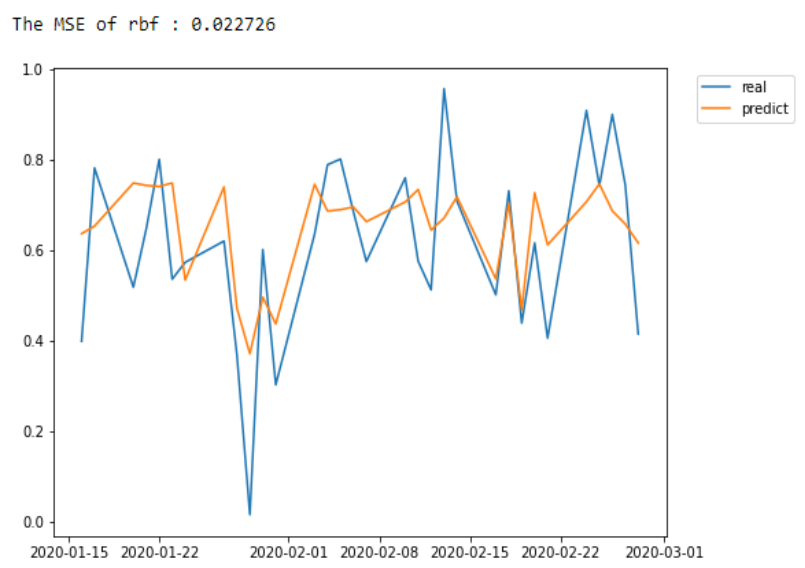

Gambar 7. Hasil Pengujian Menggunakan Kernel RBF
Pada Gambar 7 dapat diketahui bahwa kernel RBF merupakan kernel terbaik untuk digunakan pada saat prediksi, dikarenakan pada kernel RBF memberikan tingkat akurasi paling tinggi di antara tiga kernel di atas dengan MSE sebesar 0.022, atau kisaran akurasi 99.97\%, dengan kata lain prediksi menggunakan SVR pada kernel tersebut tingkat error hampir mendekati 0 .

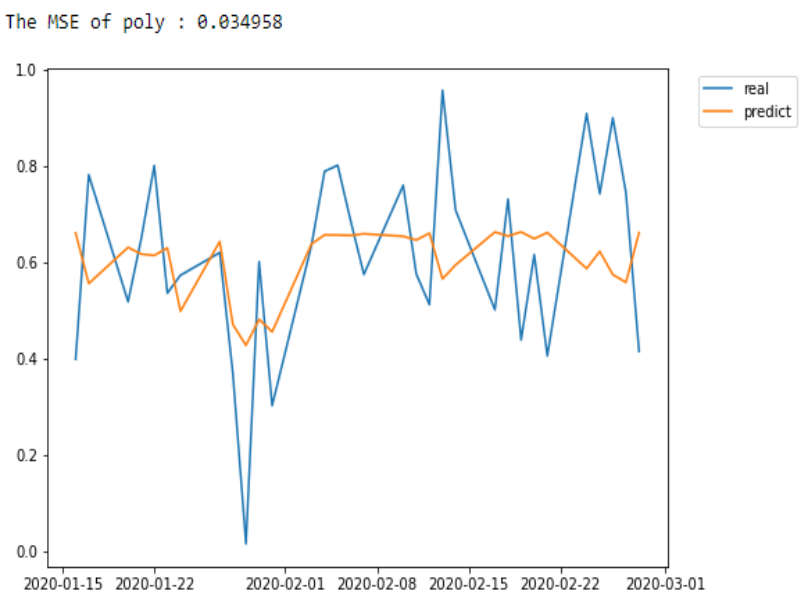

Gambar 8 Hasil Prediksi EUR/USD Menggunakan Kernel Polynomial

Selanjutnya, dilakukan pengajuan prediksi pemodelan ini dengan membandingkan hasil kernel RBF dan polynomial. Untuk hasilnya, dapat dilihat dari gambar 8 bahwa kernel polinomial tidak dapat dengan baik mengikuti pola dari pergerakan dataset yang digunakan. Nilai MSE pada saat prediksi dengan kernel polynomial 0.034 atau dengan kata lain dapat dinyatakan bahwa hasil prediksi menggunakan kernel RBF jauh lebih baik.

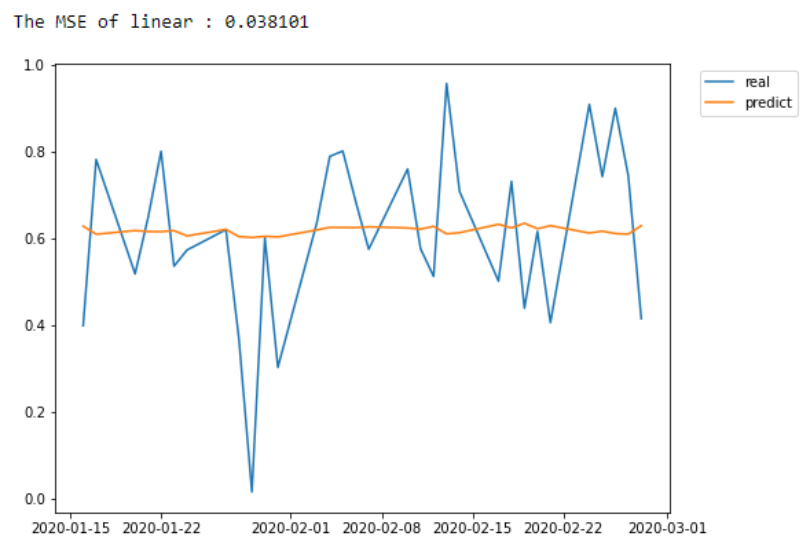

Gambar 9. Hasil Prediksi EUR/USD Menggunakan Kernel Linear

dan pada pengujian prediksi pemodelan ketiga yakni dengan membandingkan hasil kernel RBF dan linear. Diperoleh hasil yang dapat dilihat pada gambar 9 bahwa kernel linear gagal (atau terjadi underfitting) dalam membentuk pola yang mampu mengikuti fluktuasi dari data actual. Sehingga dapat dinyatakan bahwa pola linear bukan merupakan pola yang dapat digunakan untuk mempelajari trend data forex exchange EUR/USD. 
Setelah dilakukan implementasi SVR untuk memprediksi arah nilai tukar EUR/USD menggunakan kernel RBF, Polynomial dan Linear didapat hasil MSE sebesar 0.022 pada kernel RBF sehingga model SVM dengan metode SVR merupakan model yang baik untuk masalah ini. Dapat dilihat pada Tabel III mengenai sebaran akurasi nilai yang diperoleh saat memprediksi exchange forex

TABEL III. PERFormansi SVR-MSE

\begin{tabular}{|c|c|}
\hline Kernel & MSE \\
\hline Linear & 0.038101 \\
\hline Polinomial & 0.034598 \\
\hline RBF & 0.022726 \\
\hline
\end{tabular}

B. Hasil dan Analisis Prediksi Minyak Sawit Menggunakan SVM

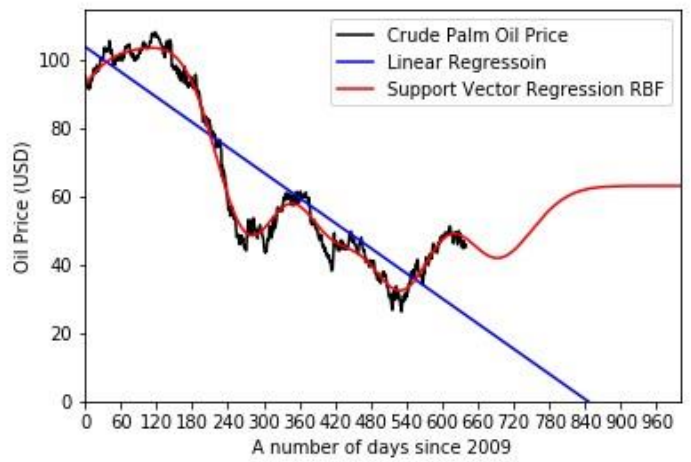

Gambar 10. Prediksi COP mulai Tahun 2009 dengan SVR RBF

Dapat dilihat pada Gambar 10 perbandingan dari Support Vector Regression dan Linear Regression. Garis merah menunjukkan hasil SVR dan garis biru menunjukkan linear regression dimana lebih optimal hasil prediksi yang di tunjukkan pada garis merah. Untuk mengukur performansi dari model yang telah dibuat digunakan Mean Absolute Percentage Error (MAPE) dan $\mathrm{R}^{2}$ yang dipengaruhi oleh model SVR terutama dalam pemilihan nilai $\mathrm{C}$ dan nilai beta. Dari pengukuran akurasi menggunakan MAPE dan R2 dapat disimpulkan bahwa evaluasi model SVR memberikan nilai yang baik dan menunjukkan validitas akurasi yang baik dari model yang telah direalisasikan dengan nilai $\mathrm{R}^{2}$ sebesar $98,83 \%$ dan nilai MAPE yaitu 4,022.

TABEL IV. Pengukuran Performansi

\begin{tabular}{|c|c|c|c|}
\hline \multirow{2}{*}{ Nilai C } & Nilai Beta & \multicolumn{2}{|c|}{ Pengukuran Performansi } \\
\cline { 3 - 4 } & Bias) & MAPE & R2 \\
\hline 100 & 0.0001 & 5.87 & 0.97 \\
\hline 600 & 0.0001 & 4.41 & 0.98 \\
\hline 1000 & 0.0001 & 4.02 & 0.98 \\
\hline 2000 & 0.00001 & 10.55 & 0.91 \\
\hline 3000 & 0.000001 & 13.33 & 0.86 \\
\hline
\end{tabular}

Pada Tabel IV dapat dilihat percobaan beberapa nilai $\mathrm{C}$ atau konstanta dan nilai beta/bias yang dimasukkan dalam input model SVR dan hasil terbaik didapat saat C $=1000$ dan nilai beta $=0.0001$ yang dipakai pada model SVR untuk melakukan prediksi harga jual minyak kelapa sawit. Nilai MAPE yang didapatkan cukup kecil yaitu 4,022 dan nilai $\mathrm{R}^{2}$ yang cukup besar yaitu 98,83 persen dimana menunjukkan model SVR dengan radial basis kernel yang dibuat cukup baik untuk memprediksi harga jual minyak kelapa sawit. Kompleksitas waktu algoritma dari support vector regression yaitu dengan nilai $O(1)+$ $O(n)$.

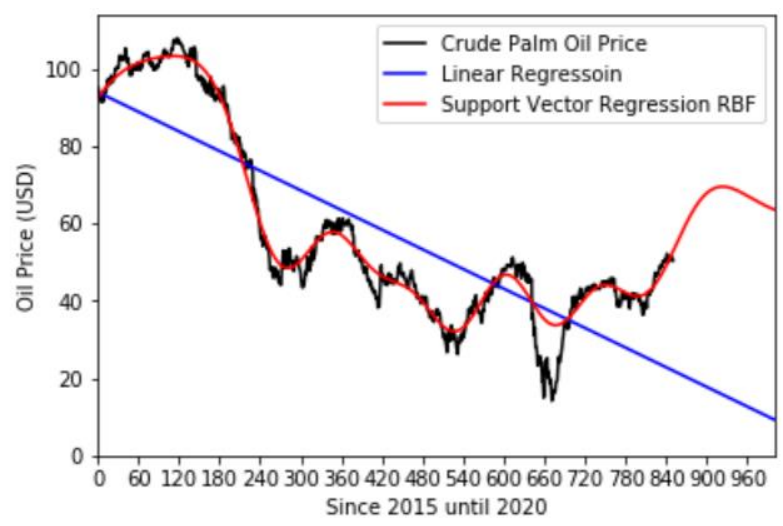

Gambar 11. Prediksi COP mulai Tahun 2015 dengan SVR RBF

Pada pengujian berikutnya dilakukan proses prediksi menggunakan dataset dari tahun 2015 sampai dengan 2020 diperoleh nilai MAPE 7.14124 dengan nilai R2 yaitu 0.9749 atau setara dengan $97.49 \%$. Gambar 11 di atas menunjukkan fluktuasi nilai prediksi yang mengalami sekitar $1 \%$ penurunan nilai akurasi dibandingkan dengan hasil pada grafik di gambar 10. Hal ini disebabkan pemodelan pada tahun awal merebak covid-19 mengalami penurunan yang signifikan, menyebabkan SVR-kernel RBF mengalam underfitting atau terjebak pada local minima untuk mengikuti pergerakan data aktual.

TABEL V. PRediksi COP 1 PeKAN Ke DePan

\begin{tabular}{|c|}
\hline Prediksi Minyak Sawit \\
\hline 69.51978919 \\
\hline 69.52813651 \\
\hline 69.53107417 \\
\hline 69.52873715 \\
\hline 69.52126253 \\
\hline 69.50878923 \\
\hline 69.49145785 \\
\hline
\end{tabular}

Pada Tabel V dapat diketahui mengenai prediksi satu minggu ke depan dari 25 Januari 2021. Dan dari hasil ini juga telah dicoba prediksi COP untuk 365 hari mendatang yaitu sampai dengan 26 Januari 2022. 


\section{KESIMPULAN}

Berdasarkan hasil pengujian dan pembahasan yang telah dilakukan, dapat ditarik kesimpulan bahwa Support Vector Machine (SVM) dengan metode Support Vector Regression (SVR) merupakan metode yang baik untuk memprediksi nilai tukar EUR/USD, terutama pada penggunaan kernel RBF di mana hasil akurasi mendekati 100\%. Namun, perlu dilakukan pemilihan kernel-SVR dengan parameter yang tepat untuk memberikan akurasi yang tinggi. Hasil yang serupa juga dapat dilihat pada saat SVR digunakan untuk memprediksi harga minyak kelapa sawit di Indonesia, di mana diperoleh akurasi prediksi pada rentang 98\%. Hal ini menunjukkan bahwa SVR mampu mengikuti pola fluktuasi dari harga minyak kelapa sawit di Indonesia.

Saran untuk penelitian di masa mendatang adalah mencoba berbagai inisiasi parameter lain untuk kernel pada model SVR yaitu pada parameter gamma, degree dan $\mathrm{C}$ dengan menggunakan kombinasi metode SVM dengan model lain seperti Deep Neural Network (DNN). Mengingat konsep Neural Network efektif untuk menangani data yang memiliki noise seperti data Forex dan/atau harga minyak kelapa sawit. Kemudian perlu dioptimasi hasil prediksi menggunakan algoritma swarm intelligence.

Mengacu kepada hasil tersebut, harapan penelitian ini dapat dijadikan sebagai salah satu referensi pemerintah dan/atau pihak yang bergerak di sektor keuangan maupun bisnis untuk dapat dijadikan sebagai tools bantuan dalam mempelajari prediksi forex trading serta prediksi harga minyak kelapa sawit, terutama dengan menggunakan dataset yang bersifat accidental seperti pada masa pandemic covid-19 yaitu pada tahun 2019-2020.

\section{DAFTAR PUSTAKA}

[1] Lu C.T., Lee and Chiu C. 2009. Financial Time Series Forecasting using Independent Component Analysis and Support Vector Regression. Taiwan.

[2] Thu T.N.T and Xuan V.D. 2018. Using Support Vector Machine in Forex Predicting. In 2018 IEEE International Conference on Innovative Research and Development (ICIRD). Bangkok.

[3] Zhao A, Zhang D and Shi J.Q. 2018. Forecasting and Analysis of EUR/USD Exchange Rate Moving Direction with Support Vector Machine in 2018 IEEE 8th Annual International Conference on CYBER Technology in Automation, Control, and Intelligent Systems, Tianjin.

[4] Raimundo s.m. and Jr J.O. 2018. SVR-Wavelet Adaptive Model for Forecasting Financial Time Series in 2018 International Conference on Information and Computer Technologies.

[5] Enri u. Februari 2018. Optimasi Parameter Support Vector Machines Untuk Prediksi Nilai Tukar Rupiah Terhadap Dollar Amerika Serikat. Jurnal Gerbang Vol.8 No.1.

[6] Sucipto a dan Zyen A.K. 2017. Pengembangan Model Support Vector Machines (SVM) Dengan Memperbanyak Dataset Untuk Prediksi Bisnis Forex Menggunakan
Metode Kernel Trick. Jurnal Informatika Upgris Vol. 3, No. 1, (2017) P/E-ISSN: 2460-4801/2447-6645.

[7] Sugianto C.A. dan Fachruddin F. 2018. Prediksi Pergerakan Harga Valas Menggunakan Algoritma Neural Network. Jurnal Informatika: Jurnal Pengembangan IT (JPIT), Vol.03, No.01, ISSN:2477-5126.

[8] Romdhoni A.A. dkk. 2013. Peramalan Nilai Tukar Mata Uang Dollar AS terhadap Rupiah Menggunakan Neural Network Ensemble Bagging. JURNAL ITSMART Vol 2. No 2. ISSN: 2301-7201.

[9] Abbas I. 2016. Penerapan Metode Moving Average (MA) Berbasis Algoritma Support Vector Machine (SVM) Untuk Membandingkan Pola Kurva Dengan Trend Kurva Pada Trading Forex Online. Jurnal Ilmiah ILKOM Volume 8 Nomor 1. ISSN: 2087-1716.

[10] Bahrany F and Crone A.F. 2013. Forecasting Foreign Exchange Rates using Support Vector Regression, an empirical Evaluation of Mean Reversion using Bollinger Bands. Computational Intelligence for Financial Engineering \& Economics (cifer), 2013 IEEE Conference.

[11] Zahrah H.H., Saadah S., and Rismala R. December 2020. The Foreign Exchange Rate Prediction Using Long-Short Term Memory: A Case Study in COVID-19 Pandemic. International Journal on Information and Communication Technology (ijoict), 6(2), 94-105.

[12] H., Yasin and C.E. Rezzy. Prediction of Crude Oil Prices using Support Vector Regression (SVR) with grid search - cross validation algorithm. Global Journal of Pure and Applied Mathematics, Volume 12, Number 4 (2016), pp. 3009-3020

[13] H. Samuel, Penerapan Sistem Fuzzy untuk Prediksi Harga Kelapa Sawit. 2016.

[14] A. M. Effendi, Analisis Harga Minyak Sawit Tinjauan Kointegrasi Harga Minyak Nabati dan Minyak Bumi. Jurnal Manajemen dan Agribisnis, Vol 7 No 1 Maret 2010.

[15] K. Adnan, I. N. Nnamdi. Intelligent Prediction of Crude Oil Price Using Support Vector Machines. SAMI 2011 9th IEEE International Symposium on Applied Machine Intelligence and Informatics, January 27-29, 2011.

[16] X. Wen, Y. Lean and W. Shouyang. A New Method for Crude Oil Price Forecasting Based on Support Vector Machines. ICCS Part IV, LNCS 3994, pp. 444-451, 2006. Springer-Verlag Berlin Heidelberg.

[17] Delima H.A., 2019, Sawit Indonesia yang Berkelanjutan, Tantangan dan Kebijakan yang Diperlukan, Peneliti Madya pada Pusat Sosial Ekonomi dan Kebijakan Pertanian, Kementerian Pertanian.

[18] Hijratul A dan Haviluddin, Juni 2019, Crude Palm Oil Prediction Based on Backpropagation Neural Network Approach, SAKTI Vol. 1, No. 1, April 2019, pp. 24-33

[19] Abdul A.K, Maret 2013, Forecasting on Crude Palm Oil Prices Using Artificial Intelligence Approaches, American Journal of Operations Research 3(2):259-267.

[20] Kim Hoong et al, 2020, Integration of machine learningbased prediction for enhanced Model's generalization: Application in photocatalytic polishing of palm oil mill effluent (POME), ScienceDirect, https://doi.org/10.1016/j.envpol.2020.115500.

[21] Kasturi K et al, 2017, Multivariate Time Series Forecasting of Crude Palm Oil Price Using Machine 
Learning Techniques, Journal IOP Conference Series Materials Science and Engineering 226(1):012117.

[22] Siti N and Xiao J, July 2010, Machine learning approach for crude oil price prediction with Artificial Neural Networks-Quantitative (ANN-Q) model, International Joint Conference on Neural Networks, IJCNN 2010, Barcelona, Spain.

[23] Nur Fazliana dkk, Juni 2018, Forecasting Crude Palm Oil Prices using Fuzzy Rule-Based Time Series Method, IEEE, https://doi.org/10.1109/ACCESS.2018.2846809

[24] Ani S and Mohd Fahmi, 2019, Wavelet-support vector machine for forecasting palm oil price, Malaysian Journal of Fundamental and Applied Sciences Vol.15 no.3.

[25] Jinzhou W et al, Oktober 2020, Ensemble probabilistic prediction approach for modeling uncertainty in crude oil price, Elsevier Applied Soft Computing, https://doi.org/10.1016/j.asoc.2020.106509

[26] Norlin K et al, Januari 2018, Crude palm oil price forecasting in Malaysia: An econometric approach, Jurnal Ekonomi Malaysia 52(3):263-278.

[27] Rasywir E. dkk, Oktober 2020, Evaluasi Pembangunan Sistem Pakar Penyakit Tanaman Sawit dengan Metode Deep Neural Network (DNN), Jurnal Media Informatika Budidarma, Volume 4, Nomor 4, Page 1206-1215.

[28] Agasta E, dkk, November 2018, Prediksi Jumlah Produksi Kelapa Sawit Dengan Menggunakan Metode Extreme Learning Machine (ELM), Jurnal Pengembangan Teknologi Informasi dan Ilmu Komputer e-ISSN: 2548964X, Vol. 2, No. 11, hlm. 5751-5759.

[29] Jacob D.S. et all, June 2019, Machine Learning Approach for Predicting Crude Oil Price Using Fuzzy Rule Based Time Series Method and Sentimental Analysis, IJCSN International Journal of Computer Science and Network, Volume 8, Issue 3, ISSN (Online): 2277-5420.

[30] Bonita O. dkk, Desember 2018, Prediksi Harga Batu Bara Menggunakan Support Vector Regression (SVR), Jurnal
Pengembangan Teknologi Informasi dan Ilmu Komputer e-ISSN: 2548-964X, Vol. 2, No. 12, hlm. 6603-6609.

[31] Mustakim dkk, Juni 2015, Support Vector Regression Untuk Prediksi Produktivitas Kelapa Sawit Di Provinsi Riau, Jurnal Sains, Teknologi dan Industri, Vol. 12, No. 2, Juni 2015, pp.179 - 188, ISSN 1693-2390 print/ISSN 2407-0939 online.

[32] Alida M and Mustikasari M, Juni 2020, Rupiah Exchange Prediction of US Dollar Using Linear, Polynomial, and Radial Basis Function Kernel in Support Vector Regression, JOIN (Jurnal Online Informatika), Volume 5 No.1 | June 2020: 53-60, DOI: 10.15575/join. v5i1.537.

[33] Raudhoti L A H, Herdiani A, dan Romadhony A. Identifikasi Cyberbullying pada Kolom Komentar Instagram dengan Metode Support Vector Machine dan Semantic Similarity. J-COSINE, Vol. 4, No. 1, Juni 2020.

[34] Eka H, Siti Saadah, Jondri. 2016. "Prediksi Ketersediaan Energi Sumber Daya Mineral di Indonesia yang di Optimasi Menggunakan Algoritma Genetika" with the title in English is Prediction of Energy Availability of Mineral Resources in Indonesia Optimized Using Genetic Algorithms. Indonesian Journal on Computing (Indo-JC). Vol.1, No.2.

[35] Hafiz, Siti Saadah, Jondri. 3-5 April 2018. Economic Growth in Indonesia based on Prediction of Production and Consumption of Energy Mineral Resources. Annual Tokyo Business Research Conference. Theme: Research for Advancement. Tokyo-Japan.

[36] Siti Saadah, Gia Septiana W. 24-26 February 2015. Interconnection Learning between Economic Indicators in Indonesia Optimized by Genetic Algorithm. 6th International Conference on Information Science and Applications (ICISA). Pattaya, Thailand. Springer Heidelberg New York Dordrecht London. 